\title{
Charring Medicinal Plants: A Traditional Method of Preparing Phytomedicines in Southwestern Nigeria.
}

\author{
A. Egunyomi, T. R. Fasola and O. Oladunjoye
}

\begin{abstract}
Charring of plant materials is a practice used by traditional Yoruba healers in Southwestern Nigeria. Samples of charred plant treatments were purchased and analyzed for their phytochemical and mineral contents. The results indicate that the treatments studied include important minerals but lack evidence of phytochemicals surviving the charring process. The conclusion is that the treatments may be effective because of minerals in the charred plants.
\end{abstract}

\section{Introduction}

In herbal medicinal practice, phytomedicines are prepared in a variety of ways including decoctions, cold and hot infusions, tinctures, ointments, powders, liniments and as poultices. However, in Southwestern Nigeria (inhabited mostly by the Yoruba), charring is a unique method of preparing phytomedicines.

Charring involves the continuous heating of fresh or dried plant material, until it turns black but without allowing it turn to ashes. Although the method appears simplistic in theory it is not so in practice as only people trained in the technique char plant materials successfully. Generally two methods are used.

Method 1: This is the open pot method. Plant parts are collected, thoroughly washed, dried and put in a large iron saucepan, which is then placed on firewood that is burning. Water is never added. The intensity of the fire is regulated in such a way that the plant parts do not burn to ash. A regular turning of the plant material is necessary. Once the material has turned black, the fire is extinguished and the burnt material left to cool. After cooling, the material is reduced to fine powder then poured into airtight containers for storage until needed for use.
Method 2: This is the closed pot method. This is exactly like the first method, except that, the materials needed are placed in an earthenware pot and covered. Occasionally the pot is opened and the materials are turned to ensure thorough mixing and complete burning. These turning periods are short to prevent more air from entering the pot as this could make the materials turn to ash (Indigenous people believe that ashes have completely lost their active components and as such are considered non-potent.).

Different reasons have been given for charring plant materials. Some people we have spoken with in Nigeria claim that it is an indirect method of preserving medicinal plants. According to this school of thought, not all plant materials are available in all seasons, so in order to keep them and to make them available when needed, the plants are reduced to charred form and in this form can be stored for a longer period of time. Another reason for charring is to reduce or eliminate the toxicity of some medicinal plants. Some practitioners hold the view that reducing plant materials to charcoal is a way of destroying the toxic substances. As most toxic substances are vola-

\section{Correspondence}

A. Egunyomi, T. R. Fasola and O. Oladunjoye, Department of Botany and Microbiology, University of Ibadan, Ibadan, NIGERIA.

aegunyomi200@yahoo.com

Ethnobotany Research \& Applications 3:261-265 (2005) 
tile compounds, these are evaporated off during the process of burning. Thus the medication becomes fit for use. Most plants in the families Fabaceae and Euphorbiaceae have been subjected to this form of preparation when needed in herbal formulations because they are considered to have high toxicity.

A material that is comparable to charred medicinal plant parts is the activated charcoal used in orthodox medicine. According to Kloss (1992), fresh charcoal made from finest woods are used for medicinal purposes. Charcoal is an absorbent and will adsorb and condense many times its volume of various gases. Activated charcoal is a black, shiny, odorless and tasteless substance. When examined under the microscope, it is extremely porous, having the appearance of a sponge with rigid walls. Charcoal acts like a magnet, attracting substances to itself and holding them tightly on to surface. It can adsorb up to 250 to 350 times its own weight.

This work investigated the process of charring medicinal plant materials that is used among the Yoruba of southwestern Nigeria. The study was carried out to ascertain the active ingredients or mineral constituents, which might be responsible for the therapeutic value of the charred phytomedicines and activated charcoal.

\section{Materials and Methods}

Table 1 includes groups of plant materials used for four different health problems. These were experimentally charred using method 2 prior to analysis.

Table 1. Plant materials used in charred form as combination treatments for four health problems by Yoruba healers of Southwestern Nigeria.

\begin{tabular}{|l|l|}
\hline $\begin{array}{l}\text { Health } \\
\text { problem }\end{array}$ & Plant materials in treatment \\
\hline Fibroids & Sphenocentrum jollyanum Pierre, fruit \\
\cline { 2 - 2 } & Calotropis procera (Aiton) Aiton f., fruit \\
\cline { 2 - 2 } & Chrysophyllum albidum G. Don, seeds \\
\cline { 2 - 2 } & Zingiber officinale Roscoe, rhizomes \\
\hline \multirow{2}{*}{$\begin{array}{l}\text { Worm } \\
\text { expulsion }\end{array}$} & Ageratum conyzoides L., seeds \\
\cline { 2 - 2 } Hemor- & Carica papaya L., seeds \\
\cline { 2 - 2 } rhoids & Raphia hookeri G. Mann \& H. Wendl., fruit \\
\hline \multirow{2}{*}{$\begin{array}{l}\text { Female } \\
\text { Sterility }\end{array}$} & Dioscorea bulbifera L., fruit \\
\cline { 2 - 2 } & Citrullis colocynthis (L.) Schrader, seeds \\
\cline { 2 - 2 } & Cissus populnea Guill \& Perr., root \\
\cline { 2 - 2 } & Chrysophyllum albidum G. Don, seeds \\
\hline
\end{tabular}

Charred samples of each of the four treatments in Table 1 were analyzed to determine the mineral constituents.
They were also screened for categories of phytochemicals to ascertain whether their therapeutic value could be attributed to the presence of some unburned biologically active ingredients.

The samples used for the different analyses are medications that have been used over the years by indigenous Yoruba herbal practitioners of Southwestern Nigeria. The plant parts were purchased from Bode Herbal market in Ibadan where they were then charred for the study.

\section{Mineral Analysis of Charred Samples}

One gram of charred plant material was weighed into $122 \mathrm{ml}$ Erlenmeyer flask, which had been previously washed with acid and distilled water. $4 \mathrm{ml}$ of perchloric acid, $25 \mathrm{ml}$ of concentrated nitric acid and $2 \mathrm{ml}$ of concentrated sulfuric acid were then added to the flask. The content was thoroughly mixed and gentle heat was applied on a hot plate under a perchloric acid fume hood. Heating was continued until dense white fumes appeared. The flask was allowed to cool and $2 \mathrm{ml}$ of concentrated nitric acid was added and heating was continued until a fuming stage occurred. Strong heat was then introduced for about 30 seconds. The content was allowed to cool and $40 \mathrm{ml}$ of distilled water was added. This was then boiled for 30 seconds in a metal plate at medium heat. After boiling was completed the solution was allowed to cool, then filtered into a $100 \mathrm{ml}$ Pyrex volumetric flask. This was made up to the mark with distilled water.

The solutions used for $\mathrm{P}$ and $\mathrm{Fe}$ determinations were stored for colorimetry while those for $\mathrm{Zn}, \mathrm{Ca}$ and $\mathrm{Mg}$ determinations were stored for atomic absorption spectrometry.

\section{Phytochemical Screening}

Based on the possibility that the charred materials might contain some organic constituents, which might account for their being therapeutic, the herbal formulations were screened for the presence of Chalcones, Tannins, Phlobatannins, Phenols, Saponins, and Flavonoids using the methods of Odebiyi and Sofowora (1978).

Tannins: Five hundred milligrams each of the charred plant parts stirred with $10 \mathrm{ml}$ of distilled water were filtered and ferric chloride reagent was added to the filtrate. Appearance of blue or blue-black, green or blue-green colouration showed the presence of tannins.

Saponins: Five hundred milligrams of charred plant materials were shaken with water in a test-tube. Persistent frothing was taken as preliminary evidence of Saponin A.

Flavonoids: Five milliliters of ethanol-extracted charred material were separately treated with four drops of concentrated hydrochloric acid, after which $0.5 \mathrm{~g}$ of Magne- 


\section{Egunyomi et al. - Charring Medicinal Plants: A Traditional Method of Preparing Phytomedicines in Southwestern Nigeria.}

sium turnings was added. Development of pink or magenta-red colouration within three minutes indicated the presence of flavonoids.

Phenol: Five hundred milligrams of the ethanol extracts of charred plant material were first extracted with ethyl acetates, and the extract was then filtered with Whatman filter paper No. 1. To $5 \mathrm{ml}$ of the filtrate, ferric chloride reagent was added. Development of blue-black or brown colouration indicated the presence of phenol.

Phlobatannins: Five milliliters of the aqueous extracts of charred plant samples were boiled with one percent hydrochloric acid. The presence of phlobatannins was indicated by the deposition of a red precipitates.

Chalcones: Two milliliters of ammonium hydroxide solution were added to $5 \mathrm{ml}$ of ethanol extract of charred plant part. Formation of a reddish color confirmed the presence of chalcones.

\section{Results}

Tables 2 to 5 show the percentage mineral constituents of charred samples for treatment of fibroids, worm expulsion, female sterility and hemorrhoids respectively. Additionally, Table 6 represents the result of a parallel sample of activated charcoal that was prepared as a control.

Table 2. Mineral constituents of charred treatment for fibroids.

\begin{tabular}{|l|l|l|}
\hline Mineral & Mg/dl & Percentage (\%) \\
\hline Chlorine & 992.6 & 0.099 \\
\hline lodine & 773.5 & 0.077 \\
\hline Sulphur & 499.5 & 0.0499 \\
\hline Phosphorus & 2289.9 & 0.23 \\
\hline Boron & 19.695 & 0.00197 \\
\hline Calcium & 2200 & 0.22 \\
\hline Sodium & 3800 & 0.38 \\
\hline Potassium & 4100 & 0.41 \\
\hline Magnesium & 130 & 0.013 \\
\hline Iron & 43 & 0.0043 \\
\hline Zinc & 23 & 0.0023 \\
\hline Copper & 7.870 & 0.00079 \\
\hline Selenium & 4.182 & 0.00042 \\
\hline Chromium & 1.9 & 0.00019 \\
\hline Vanadium & 2.1 & 0.00021 \\
\hline Manganese & 28 & 0.0028 \\
\hline
\end{tabular}

Table 3. Mineral constituents of charred treatment for worm expulsion.

\begin{tabular}{|l|l|l|}
\hline Mineral & Mg/dl & Percentage (\%) \\
\hline Chlorine & 334.5 & 0.035 \\
\hline lodine & 552.5 & 0.055 \\
\hline Sulphur & 66.0 & 0.0666 \\
\hline Phosphorus & 1885.8 & 0.19 \\
\hline Boron & 6.565 & 0.000656 \\
\hline Calcium & 1800 & 0.18 \\
\hline Sodium & 1800 & 0.18 \\
\hline Potassium & 2800 & 0.28 \\
\hline Magnesium & 110 & 0.011 \\
\hline Iron & 34 & 0.0034 \\
\hline Zinc & 18 & 0.0018 \\
\hline Copper & 3.148 & 0.00031 \\
\hline Selenium & 2.321 & 0.00023 \\
\hline Chromium & 1.4 & 0.00014 \\
\hline Vanadium & 2.9 & 0.00029 \\
\hline Manganese & 16 & 0.0016 \\
\hline & &
\end{tabular}

Table 4. Mineral constituents of charred treatment for female sterility.

\begin{tabular}{|l|l|l|}
\hline Mineral & Mg/dl & Percentage (\%) \\
\hline Chlorine & 212.7 & 0.021 \\
\hline lodine & 331.5 & 0.033 \\
\hline Sulphur & 333.0 & 0.033 \\
\hline Phosphorus & 1616.4 & 0.16 \\
\hline Boron & 9.848 & 0.000985 \\
\hline Calcium & 1500 & 0.15 \\
\hline Sodium & 2900 & 0.29 \\
\hline Potassium & 3100 & 0.31 \\
\hline Magnesium & 310 & 0.031 \\
\hline Iron & 21 & 0.0021 \\
\hline Zinc & 7.5 & 0.00075 \\
\hline Copper & 4.722 & 0.00047 \\
\hline Selenium & 1.812 & 0.00018 \\
\hline Chromium & 2.6 & 0.00026 \\
\hline Vanadium & 1.5 & 0.00015 \\
\hline Manganese & 33 & 0.0033 \\
\hline
\end{tabular}


Table 5. Mineral constituents of charred treatment for hemorrhoids.

\begin{tabular}{|l|l|l|}
\hline Mineral & Mg/dl & Percentage (\%) \\
\hline Chlorine & 141.8 & 0.014 \\
\hline lodine & 221.0 & 0.022 \\
\hline Sulphur & 166.5 & 0.00167 \\
\hline Phosphorus & 1212.3 & 0.12 \\
\hline Boron & 3.283 & 0.000328 \\
\hline Calcium & 1100 & 0.11 \\
\hline Sodium & 1300 & 0.13 \\
\hline Potassium & 2100 & 0.21 \\
\hline Magnesium & 150 & 0.015 \\
\hline Iron & 16 & 0.0016 \\
\hline Zinc & 25 & 0.0025 \\
\hline Copper & 2.296 & 0.0023 \\
\hline Selenium & 3.161 & 0.00032 \\
\hline Chromium & 3.7 & 0.00037 \\
\hline Vanadium & 3.2 & 0.0032 \\
\hline Manganese & 21 & 0.0021 \\
\hline
\end{tabular}

Table 6. Mineral constituents of activated charcoal (Control).

\begin{tabular}{|l|l|l|}
\hline Mineral & Mg/dl & Percentage (\%) \\
\hline Chlorine & 177.14 & 0.018 \\
\hline lodine & 128.26 & 0.013 \\
\hline Sulphur & 238.62 & 0.024 \\
\hline Phosphorus & 974.20 & 0.097 \\
\hline Boron & 5.17 & 0.000517 \\
\hline Calcium & 1200 & 0.12 \\
\hline Sodium & 1400 & 0.14 \\
\hline Potassium & 1510 & 0.151 \\
\hline Magnesium & 125 & 0.013 \\
\hline Iron & 28 & 0.0028 \\
\hline Zinc & 13 & 0.0013 \\
\hline Copper & 3.52 & 0.00035 \\
\hline Selenium & 2.00 & 0.00020 \\
\hline Chromium & 2.7 & 0.00027 \\
\hline Vanadium & 1.7 & 0.00017 \\
\hline Manganese & 15 & 0.0015 \\
\hline
\end{tabular}

\section{Phytochemical Tests}

All the charred samples analyzed phytochemically, tested negative to all the phytochemical tests, indicating the absence of any active ingredient.

\section{Discussion}

As shown in Tables 2-4, the most abundant inorganic macronutrients in each of the charred phytomedicines are sodium, potassium, calcium, magnesium and phosphorus. These minerals constitute the major part of the buffer ions in human body fluids.

Sodium acts with other electrolytes especially potassium in the intracellular fluid, to regulate the osmotic pressure and maintain proper water balance with the body. It is required for glucose absorption and for transportation of other nutrients across cell membranes (Bakhru 1999). In addition, normal functioning of the nervous system depends on sodium. Potassium is also important because both sodium and potassium maintain a balance to promote the regulation of water balance within the body.

Calcium is essential for proper utilization of phosphorus and Vitamin A, D and C and speeds all healing processes in the human body (Pamplona-Roger 1998). Apart from helping to control muscle growth and electrical impulses in the brain, calcium is involved in the maintenance of proper blood pressure and blood clotting. The importance of magnesium is that it helps in the utilization of Vitamins $B$ and $E$ and functions with other minerals such as calcium, sodium and potassium in maintaining fluid and electrolyte balance (Bakhru 1999). The element is needed for proper growth formation and function of bones and muscles. Bakhru (1999) states that phosphorus is required for all active tissues in humans. It is essential in chemical process involved in utilization of carbohydrate and fats. In addition, it is a part of body energy storage system.

Minor minerals are very important because they can affect vital life processes. As an example although a person's daily intake of chromium is $0.007 \mathrm{mg}$, Pyke (1975) reported that the micronutrient is important in maintaining appropriate blood glucose levels. The role of microelements as biocatalysts in certain chemical reactions in living beings was reported by Pamplona-Roger (1998). Micronutrients that are consistently of relatively high values in each of the charred medications are zinc, copper, manganese, selenium and boron. Zinc is involved in well over one hundred different reactions, some of which help the body synthesize and maintain DNA. Almost all the enzymes in the body require $\mathrm{Zn}$ for their functioning and is one of the most important elements to a healthy immune system (Bakhru 1999).

Copper as an essential nutrient is found in some protein and enzymes some of which are needed for the proper utilization of iron. It is involved in respiration and is an important antioxidant. Additionally, it is involved in protein metabolism and healing processes. A prolonged deficiency of manganese in human body may cause male and female sterility as well as sexual impotence in male. 


\section{Egunyomi et al. - Charring Medicinal Plants: A Traditional Method of Preparing Phytomedicines in Southwestern Nigeria.}

Bakhru (1999) also know that manganese activate numerous enzymes and has roles in protein, carbohydrate and fat metabolism.

Although selenium is a toxic heavy metal, it is very important for human health. Together with Vitamin E, selenium helps the immune system produce antibodies. Selenium binds toxic metals like mercury and is involved in promotion of normal body growth and fertility. Shealey (1998) reports that the micronutrient Boron raises testosterone levels in men and promotes the proper functioning of calcium, magnesium and phosphorus. Boron prevents tumors and cysts (Bakhru 1999). The fibroid medication in this study has the highest quantity of boron. As shown in Table 5 , the mineral constituents of activated charcoal used as control are similar to those of the charred phytomedicines. It is therefore most likely that the charred medications can be used like the activated charcoal in orthodox medicine.

\section{Conclusions}

In spite of the fact that this paper has not linked a particular element or combination of elements directly to a particular health problem, it is likely (since phytochemicals were not found in the charred medications) that the macro- and micro-nutrients must be responsible for any therapeutic value of the treatments. Since the most abundant micro- and macro-nutrients highlighted are of immense value in promoting health, their presence in the charred phytomedicines would make up for any deficiency. This is in keeping with the opinion of many ethnomedicinal practitioners that if all the necessary nutrients are provided in humans, all cases of disease will disappear.

Charring as a method of presenting phytomedicines has implications for conservation of the plants. As storage of plants may be difficult thus encouraging continuous harvesting of fresh plants thereby de-populating them. Charring converts phytomedicines into stable forms that can be preserved in air-tight bottles for a considerable period of time. This will reduce the frequency of harvesting fresh plants from the forest.

\section{Literature Cited}

Bakhru, H.K. 1999. Vitamins that heal. Orient Paperbacks Delhi, India.

Kloss, J. 1992. Back to Eden. Revised and Expanded. Second Edition 1992. Back to Eden Publishing Co., California.

Odebiyi, O.O. \& E.A. Sofowora. 1978. Phytochemical Screening of Nigerian Medicinal Plants. Lloydia 41:234.

Pamplona-Roger, D. 1998. Encyclopedia of Medicinal Plants. Editorial Saeliz, Spain.
Shealy, C.N. 1998. The Illustrated Encyclopedia of Heavy Remedies. Element Books Ltd. Great Britain. 
